\title{
Enacting Orthodoxy in Walter Martin's The Kingdom of the
}

\author{
Cults \\ Nathan Schneider \\ $1^{\text {st }}$ Year, PhD Religious Studies \\ University of California, Santa Barbara \\ Santa Barbara, California
}

Compared to the bourgeoning discussions about heresiology in antiquity, especially connected to broader ones about constructions of orthodoxy, very much less has been said about more contemporary examples of this tradition, which, assuredly, is alive and well. Particularly in evangelical Christian circles, there are numerous books available that list, describe, and evaluate the ever-expanding choices people have in the marketplace of religious ideas. Meanwhile, scholars of antiquity have come to realize the significance of this literary genre in the "production" of difference among communities as well as, in certain circumstances, of what came to be called orthodoxies. Daniel Boyarin goes so far as to suggest that heresiology pioneered the concept of religion itself as an autonomous, identity-forming phenomenon. ${ }^{1}$ Claims like these should lead us to be more alert about the presence and influence of this genre as it is expressed in our own time, the role it has played recently, and that which it is playing now. The apparently globalizing world certainly makes the turn of the 21 st century at least as formative a time for spiritual categories, boundaries, and authorities as late antiquity, when the Roman

${ }^{1}$ Boyarin, Border Lines, 202-211. 
Empire underwent such dramatic religious transformations.

In this paper I examine a "classic" heresiology of the American evangelical countercult movement, Dr. Walter Martin's Kingdom of the Cults. First published in 1965, it has been continuously updated every decade since, even after the author's death in 1989, most recently in 2003 under the auspices of Martin's daughter and son-in-law. ${ }^{2}$ Beginning with a discussion of the book as well as Martin himself, I develop an account of the concepts of orthodoxy and cult at work in it. With them in mind, and looking into the purpose and audience that Martin imagines for the book, I outline the role of praxis (or performance) in the "production" of the orthodox community. The Kingdom is explicitly both scholarship and a practical primer, for its theory of orthodoxy cannot be separated from the work of evangelizing. Performing right belief in this way, however, should not be thought of as orthopraxis; it does not create boundaries through activity so much as it works to establish boundaries of belief. Briefly at the end, I consider the Kingdom in comparison to Epiphanius's Panarion, a fourth-century heresiology. My intention in doing this is to demonstrate their affinity in genre as well as some major differences in approach. The contrast may help to elucidate the unique features of Martin's orthodoxy.

\section{Martin and His Kingdom}

Largely because of The Kingdom of the Cults, his most extensive and bestselling work,

\footnotetext{
${ }^{2}$ Martin, The Kingdom of the Cults (1965); The Kingdom of the Cults (2003). Consequently I will refer to these editions in shorthand by publication date, e.g. KC 1965, 1.
} 
Walter Martin has been called the father of the modern countercult movement. Born in Brooklyn in 1928, he studied religious education at a handful of Bible colleges and received an M.A. from New York University, followed two decades later by a Ph.D.from California Coast University, a distance-learning institution. ${ }^{3}$ Martin's offical biographies make much of his advanced degrees and several times in the course of the book he describes himself as a college professor and an ordained minister. In general his education has been the subject of a great deal of dispute, especially when a pair of Mormon apologists questioned whether he ever in fact completed his Master's thesis and the legitimacy of his doctorate. ${ }^{4}$ For six years he served as Associate of Biblical Studies at the King's College in Briarcliff Manor, New York. He held other faculty positions as well and was a member of the American Academy of Religion and the Society of Biblical Literature. The same two Mormon critics allege that the Martin's ordination was not valid, having been revoked on the event of his second marriage. The Walter Martin Ministries website, however, has posted a letter from the California Southern Baptist Convention that his ordination was indeed recognized as late as $1998 .{ }^{5}$ Nevertheless, as he presented himself and was received by his supporters, the Reverend Dr. Walter Martin was a Baptist minister, scholar, professor, and evangelist all in one.

Throughout his life, he appears to have had a single-minded commitment to countercult work, fueled by impressive entreprenurial fervor. "I know of no one who

\footnotetext{
${ }^{3}$ Cowan, "Historical Figures in the Christian Countercult Movement: Walter R. Martin,"; Martin, "Walter Martin's Religious InfoNet - Biography."

${ }^{4}$ Robert and Rosemary Brown's They Lie in Wait to Deceive: A Study in Anti-Mormon Deception, quoted in Cowan.

${ }^{5}$ Cowan; http://www.waltermartin.org/ordain.html.
} 
equals him in this field," Billy Graham reportedly said of Martin. ${ }^{6}$ In 1955 he founded the Zondervan Publishing House's Division of Cult Apologetics, which he managed for ten years. During that time he also began building up his Institute for Christian Research, a countercult think-tank that is still recognized as a leader in its field today. He wrote for many of the most important evangelical magazines, including Christianity Today and Action, where he worked as an Editorial Research Associate. His activism brought him a great deal of visibility in the evangelical world, including appearances on The $700 \mathrm{Club}$ and numerous Christian radio programs. By 1965, the same year the Kingdom was first published, Martin became "The Bible Answer Man" on his own popular call-in radio show. It, along with the ICR, are now under the control of Hank Hanegraaff, who also edited the 1997 edition of the Kingdom. The Martin family, which operates Walter Martin Ministries (www.waltermartin.org), has denounced Hanegraaff, and he is absent from the 2003 edition.

Martin's legacy continues to be surrounded by controversy. The groups that he profiled and opposed, especially the Mormons, have put real work into discrediting him. But even a supporter has described him as a "person of monumental ego who gave a highly misleading picture of himself." ${ }^{\prime 7}$ Another Mormon group, on the grounds of a police report, has claimed that the Martin family invented a public "myth" to tell about the way in which the apologist died. According to the report, he was found dead slumped over a toilet, though the family maintained that he died peacefully in bed after a session of prayer. ${ }^{8}$ The attention that Martin's critics pay to such gruesome details gives some

${ }^{6}$ Martin, "Walter Martin's Religious InfoNet - Biography."

M. James Penton (unpublished manuscript), quoted in Cowan.

8 SHIELDS, "The Myth Surrounding Walter Martin's Death." 
idea of the resentment his work managed to conjure.

In its five editions and dozens of printings, The Kingdom of the Cults has reportedly sold more than 750,000 copies. According to Newsweek, the 1985 edition was "one of the bestselling spiritual books in America." 9 Scholars of the countercult movement take the book's influence seriously: "Others," writes one, "generally less thorough, have tried to imitate Martin, but his work remains the standard." ${ }^{10}$ Forty years after the bulk of it was written, the 2003 edition, a 700-page hardcover with a mesmerizing swirl of colors on the front, is still a staple on the shelves of Christian bookstores. It includes charts, bullet points at the beginning of each chapter for quick reference, and Chicago-style footnotes. The dustjacket makes great claims: "The definitive work on the subject," Completely updated for the 21st century," and "The leading cult reference tool now completely updated! "Under Martin's name is that of another well-known apologist, Ravi Zacharias, who served as general editor under the auspicies of Martin's daughter and son-in-law. In comparason, the 1965 edition is much more subdued. There are neither charts, footnotes, nor bullet points. Nevertheless the core of all the editions is the same. His posthumous editors have been careful to preserve Martin's original voice, which sometimes leads to hodgepodge. “A man's words are a man's words," they insist in their preface. ${ }^{11}$ The Kingdom's publication life has been a performance in the authoritative. As control of it has passed from Martin's hands to Hanegraaff's, and now to those of Martin's family, it has maintained audience, relevance, and mystique. For much of this it is indebted to the persona of Martin himself.

\footnotetext{
9 Martin, "Walter Martin's Religious InfoNet - Biography."

${ }^{10}$ Shupe, Six Perspectives on New Religions, 70.

${ }^{11}$ KC 2003, "Managing Editors' Preface." Here the managing editors, Martin's daughter and son-in-law, Jill Martin Rische and Kevin Rische, are quoting Ravi Zacharias.
} 
The Kingdom is laid out as a catalog of cults, each treated one at a time in no ostensibly significant order, ${ }^{12}$ preceded and followed by a handful of chapters about methodology and countercult practice. Each cult's history and doctrines are explained at length, then concisely refuted, usually through biblical proof texts. He likely draws this basic format from several earlier cult books that he refers to in the first chapter, all of which look rather similar on the table of contents page in terms of format and the particular cults covered. ${ }^{13}$ All limit themselves to mainly American cults. With one exception, they accept the term "cult," whatever it may mean for them. When compared to some of the other books that sit alongside the 2003 Kingdom in Christian bookstores, it is clear that they form a common genre. Some, like Beverly's Religions A to Z, which describes exactly 100 traditions great and small, apply a rigid, artificial taxonomy. Others, like Carlson and Decker's Fast Facts on False Teachings, address commonly misleading notions like evolution and yoga that aren't necessarily associated with a bounded group.

Over the course of editions, the table of contents shifts somewhat. Some cults are added, some are removed, and some switch places. Later editions reflect more interest in world religions, which causes some tension with the original sense of "cult" that Martin seems to have been using. In this way and others, the editors depart somewhat from his

\footnotetext{
${ }^{12}$ If anything, the order may be Martin's own idea of the cults' significance. Originally, the first three are what were considered the "Big Three" (as noted by Shupe, Six Perspectives on New Religions, 71) cultic threats: Jehovah's Witnesses, Christian Science, and Mormonism. These first three are the longest chapters in the book and were also each the subject of separate books by Martin. The 2003 edition makes a point of returning to Martin's original order wherever possible.

${ }^{13}$ These include two liberal Christian works, Bach, They Have Found a Faith; Branden, These Also; and one rather more in line with Martin sans somewhat his zeal, Van Baalen, The Chaos of the Cults.
} 
original methodology that is my main interest in the next two sections. These choices seem to be the honest result of recent events and cultural developments. The inclusion of Islam for instance, rather than only the Nation of Islam ("The Black Muslim Cult" in KC 1965), reflects the editors' sensation of "its growing presence in the United States and its influence in American religious life." 14

As of yet, the secular academic literature has not paid close attention to either Martin or the Kingdom of the Cults. Those discussions that do exist have addressed the man and his work mainly in the comparative context of Christian responses to new religious movements rather than concepts and constructions of community within recent Christianity. The most complete among these is Douglas Cowan's Bearing False Witness? An Introduction to the Christian Countercult, which points out ways that new religions have been misleadingly represented. Two other discussions, by Anson Shupe and John Saliba, take similar approaches. ${ }^{15}$ All three recognize the important characteristics of Martin's orthodoxy, though they do not concern themselves so much with its consequences for Martin's church as for the cults. By reading the Kingdom for its consequences on the community it is intended for, I take a different approach.

\section{The "Ramparts" of Orthodoxy}

In the first pages of the Kingdom, Martin sets out his assumptions dramatically:

It has been wisely observed by someone that "a man who will not stand for

\footnotetext{
${ }^{14} \mathrm{KC} \mathrm{2003,435}$

${ }^{15}$ Cowan, Bearing False Witness?; Saliba, Understanding New Religious Movements; Shupe, Six Perspectives on New Religions.
} 
something is quite likely to fall for almost anything." So I have elected to stand on the ramparts of biblical Christianity as taught by the apostles, defended by the church Fathers, rediscovered by the Reformers, and embodied in what is sometimes called Reformed Theology. ${ }^{16}$

By stating his position in this way, he makes clear that the theory of the cult depends on the theory of religious truth. In an earlier work, he explains, "Cultism, in short, is any major deviation from orthodox Christianity relative to the cardinal doctrines of the Christian faith."17 The orthodoxy that he takes to be a given throughout the book operates as a static pivot. As a shorthand, he describes it as "historical" or "biblical" Christianity, and avoids calling any cult "Christian" even if they describe themselves as such. With it he introduces a discourse of purity, which Daniel Boyarin links to the assumptions of heresiology in antiquity:

Heresiology is not only, as it is usually figured, the insistence on some (or another) right doctrine but on a discourse of the pure as opposed to the hybrid, a discourse that then requires the hybrid as its opposite term. ${ }^{18}$

In a passing reference, he attributes most such "deviation" to a tempting theology of autosoterism (which he draws from Van Baalen), "the desire to save one's self apart from biblical revelation,"19 and in another place, to simple "spiritual blindness.",20

A theory such as this resists the dynamic, second-order heresy/orthodoxy formulations that have been discussed since Walter Bauer's 1934 Orthodoxy and Heresy in Earliest Christianity. From Bauer to contemporary writers like Rowan Williams, in some way or another, orthodoxy is thought to develop in contrast to and in dialog with existing others, the heresies. What we come to call orthodoxy then, is not so much

${ }^{16} \mathrm{KC} 1965,11-12$; KC 2003, 18.

17 From The Rise of the Cults (1955), quoted in Cowan.

${ }^{18}$ Boyarin, Border Lines, 208.

${ }^{19} \mathrm{KC} 1965$ 12; KC 2003, 18.

${ }^{20} \mathrm{KC} 1965$ 27; KC 2003, 40. 
intrinsically truthful as it happens to be the ideology of the victors. ${ }^{21}$ Against dynamic models, Martin clearly upholds its first-order meaning as a static and intrinsic truth. At the same time, his deviation model of heresy assumes the kind of continuous, stable transmission of this truth "as taught by the apostles" that Bauer felt need to reject on historical-critical grounds. On this point Martin is both insistent and confident: "We cannot afford to hold any concept of the purveyors of erroneous doctrines different from that held by our Lord and the apostles.",22

Nevertheless, the static, doctrinal model that Martin employs makes what he calls a "cult" appear closer to the received meaning of "heresy" that thinkers like Bauer and Williams discuss, a false belief or opinion. The cult, in its usual formulation and Latin root, refers more to a sociological group that sets itself apart from the mainstream. Many of his sources, particularly Branden, understand the cult in this way: "any religious group which differs significantly...from those religious groups which are regarded as the normative expression of religion in our total culture. ${ }^{, 23}$ Because the term is usually understood as derogatory, another of Martin's liberal sources, Marcus Bach, conspicuously avoids it. The non-theological anti-cult movement (which scholars call ACM) relies on this sociological formulation of the cult as the basis of its polemic. By implying a bounded group, the term "cult" serves to reify, establishing it as a definite other. Together, these aggregate bounded others constitute Martin's grand metaphor of the "kingdom," with all of its cosmic and demonic overtones. Throughout the book cultism of various sorts is described as on the rise, and offering the latest threatening facts

\footnotetext{
${ }^{21}$ Bauer, Orthodoxy and Heresy in Earliest Christianity; Desjardin, "Bauer and Beyond"; Rowan Williams, "Does It Make Sense to Speak of Pre-Nicene Orthodoxy?"

${ }^{22} \mathrm{KC} 2003,22$. Absent from KC 1965.

${ }^{23}$ Branden, These Also Believe, xii. Quoted in KC 1965, 11; KC 2003, 17.
} 
and figures is a particular habit of Martin's posthumous editors - they insist that to this day "the kingdom of the cults is expanding." 24 This phrase comes to serve as a terrifying mantra. By using "cult" in this way and in this context, Martin and his editors benefit rhetorically from both the sociological and doctrinal implications of the word.

The third chapter, titled "The Psychological Structure of Cultism," deals with the modes of authority and social control that are present in cult communities. It appears at first to prepare a refutation based on sociological models, but a closer reading reveals these critiques to be incomplete. Though it does paint an image of the cults as stubborn and manipulative, it does not clearly distinguish between cults and true Christianity. Stubbornness, after all, is a virtue for an orthodox Christian and the cultist alike. Both Shupe and Saliba point this out as well; because of Martin's own sympathy with some of their characteristics, the sociological or psychological models of the cult are not his grounds for refuting it. Explicitly, he rejects "sociological or cultural evaluation" of cults; "the answer of the church must be theological and doctrinal." ${ }^{25}$ Instead, he employs these models in two ways, kept quite separate from the theory of orthodoxy: (1) negative associations with the word "cult" itself, derived from ACM usage and that of his sources, and (2) psychological and social tools for apologetic praxis, for understanding and combating cult organizations. Despite these ways in which they are useful for him, nondoctrinal models are essentially foreign to his prevailing framework.

The Kingdom's second chapter, "Scaling the Language Barrier," describes the foundation for a static model of biblical Christianity. Its borders lie in its lexicon and, following Boyarin, they generate a discourse of lexical purity. "Defining terminology,"

${ }^{24} \mathrm{KC} 2003,23$, among other places.

${ }^{25}$ Quoting Dr. Lee Bedford of NYU, KC 1965, 17; KC 2003, 24. 
he writes, "is what we might call the key to understanding cultism." ${ }^{26}$ What makes it so difficult for Christians to reach out to cult members is that, as a rule, cults teach different meanings for important terms in the Bible. Many cults, including Christian Science and the Unity School, publish their own glossaries that do just this. Through their invented definitions, cultists are able to do two things: (1) confuse and surprise people who believe the Bible but do not know it well enough to detect falsehood, and (2) allow for a misleading "surface agreement" between them and orthodox interlocutors, using terms in such a way that sounds familiar but all the while dangerously reinterpreting them. But these readings are tautologically false ones: "the vocabulary of the cults is not the vocabulary of the Bible by definition."

Against such confusion, Martin insists on the lexical consistency of theological terms, for "in context words mean just what they say." ${ }^{27}$ The "historically accepted meanings" of these words should be evident, and can be confirmed through actual familiarity with scripture. No reinterpretation can withstand the test of scrutiny. If we abandon the obvious historical definitions, we can throw the whole rest of language out as well:

Either we admit this or we must be prepared to surrender all the accomplishments of grammar and scholastic progress and return to writing on cave walls with charcoal sticks in the tradition of our alleged [emphasis mine] ancestors. ${ }^{28}$

The challenge, as he phrases it, is for believers to know the true meanings of doctrinal terms well and to challenge cultists to define the words they use outright. He suggests

${ }^{26} \mathrm{KC}$ 1965, 18-19; KC 2003, 28-29.

${ }^{27} \mathrm{KC} 1965,21$; KC 2003, 30.

${ }^{28}$ Ibid. As a student of the evolution debates, I appreciate the way Martin here references the cultural idea of primitive people (and the existence of their evidence) without admitting that they ever existed. 
that key dogmatic doctrines like original sin, the Atonement, and the Trinity, can be used as a litmus test for the definitions that people offer; if the definitions resist any of these doctrines, they are not truly historical or biblical.

Throughout, the whole discussion of terminology is placed in this dialogic formula, the context of the apologetic encounter. Martin suggests what questions to ask and strategies for answering the proofs of others. Sensitivity to the lexicon is not only a theoretical approach to a circumscribed orthodoxy, but also a practical method for defending it. So far as he develops a theory, it is a theory written in the language of strategy and practice.

Martin's model of static orthodoxy is both powerful and limited. While it claims to offer the Bible as an ironclad litmus test for the reliability of doctrines, it also depends heavily on a context and audience that takes the Bible to be religious truth in the first place. He assumes that "most cultists utilize terminology of historical Christianity," and "all major cult systems will use the Bible." ${ }^{29}$ The coherence of his entire project depends on a readership that accepts the supreme authority of scripture, that can join him on his "ramparts." From there, the focus of his interest is on the "proximate other," ${ }^{30}$ those who accept the same scriptures and call themselves Christians, like the Jehovah's Witnesses and the Mormons. Only then, with a much more limited treatment, does he turn to groups like Baha'is and Muslims who do not recognize the Bible's authority in the same way. With them, the lexical theory of biblical orthodoxy is not so effective a model of refuting individual cultists. It becomes more difficult to enact in apologetic encounters. Without the shared source of authority, orthodoxy becomes less an enacted engagement

${ }^{29} \mathrm{KC} \mathrm{1965,333;} \mathrm{KC} \mathrm{2003,} 466$.

${ }^{30}$ To use the phrase Daniel Boyarin is so fond of. 
with the cultists than an exercise in mere theory for the bible-believing audience.

The borders that Martin's orthodoxy draws are not always clear, but he does make an effort to elucidate them. The Kingdom addresses borderline cases with interest and vigor, particularly Seventh-Day Adventism and the Worldwide Church of God. Martin took a controversial stand among evangelicals by contending that, despite a few incorrect doctrines, Adventism is essentially an orthodox expression of Christianity. The Worldwide Church of God, which in the first edition (where it is called Anglo-Israelism) had a chapter outside of the appendix and classified as a full-fledged cult, was later moved to the appendix under the subtitle, "From Cult to Christianity." The 2003 edition describes the group's adoption, by the influence of new leadership, of orthodox teaching. "Cults come and go," it explains, "but rare indeed is the repentance of cult leadership that results in heresy being replaced with biblical Christianity. Such is the story of the Worldwide Church of God." 31 With these two borderline cases, the Kingdom further explicates its concept of the static orthodoxy. The Worldwide Church of God's conversion demonstrates that cultism is not a feature of a group or lineage but by the content of its teachings. Adventism serves as a reminder that even a group with strange practices and a few unfamiliar beliefs, if it gets the basics right, can still be considered a valid part of the church.

Within his own community, Martin carefully defends a certain level of diversity. He distinguishes between cultic false doctrines and the "certain peripheral issues" of

\footnotetext{
${ }^{31}$ KC 2003, 507. I should note that the Worldwide Church of God's migration occured not under the auspices of Martin but of one of the later editors, Kurt Van Gorden. Nevertheless, unlike some other revisions of the posthumous editors, I see no disagreement between this move and Martin's explicit methodology.
} 
disagreement among Christians, which should not be taken as the sign of Satan. ${ }^{32}$ Centered around the cardinal "historical" and "biblical" doctrines, the boundaries of the church are clear, and a catechized Christian community will only make them stronger. In different places, he appears to take a stand on at least two areas that theologian Roger E. Olsen recently identified as the critical "tensions" in evangelical theology: the leadership of women and "postmodernity." 33 In each case, Martin falls on the conservative end. Since he wrote over forty years ago, this should not be surprising. But because the latest edition came out the same year as Olsen's article, this kind of internal polemic may be intentional on the part of the editors and executors. For the most part, though, the Kingdom serves as a basis for unity rather than division.

Sociologically, Martin's "in-group," the community of his orthodoxy, is a far cry from the elegant unity of his doctrine. As we see with the Worldwide Church of God, groups and leaders can come and go from it. The organization itself does not carry sacramental value. He talks about the Christian "church" as a locatable, identifiable, and bounded entity, but the people he actually seems to be referring to are scattered among the denominations, affiliations, and places that make up evangelicalism in the United States. Their unity, expressed through doctrine, is essentially spiritual and expressly not sociological. It rests on a theory of the coherence of scripture and the reliability of historically-accepted dogma. The doctrinal emphasis reacts directly to the axiomatic

\footnotetext{
${ }^{32} \mathrm{KC} 1965,335$; KC 2003, 470. In 1965, it reads simply "certain issues."

${ }^{33}$ Olsen, "Tensions in Evangelical Theology." (1 - leadership of women) In the chapter on the Theosophical Society, using the examples of Mary Baker Eddy, Annie Besant, Helena Blavatsky, and others, Martin recalls Paul's injunction "to forbid women the teaching ministry" (KC 1965 225), or rather, "to forbid women to usurp authority over the male head" (KC 2003, 286). (2 - postmodernity) I take the Kingdom's doctrine of lexical veracity to be an affront what Olsen describes as the "themes of postmodernity," particularly "theology as a second-order language" (Olsen, 82).
} 
disunity of Martin's community, sidestepping it, and assuring that denominational differences are beside the point. As is a final sociological analysis of cults and new religious movements in general, such as the $\mathrm{ACM}$ is liable to do. In developing a practicable lexical theory for refuting cults, Martin very clearly circumscribes the boundaries of the Christian church as he sees it while affirming its unity.

Departing from the liberalism of his predecessors Bach and Branden, Martin defines a static concept of Christian orthodoxy founded in his assurance of a "historical," reliable Christian lexicon and the authority of the Bible. With these he sets out a threefold program for each cult: "historical analysis," "theological evaluation," and "apologetic contrast." 34 The intended apologetic program, which I explore in the next section, makes the practicable rigidity of the Kingdom's theory of orthodoxy particularly attractive. Through this practice, the church internalizes the doctrinal conception of purity and unity.

\section{Put into Action}

In one of his many audio lectures, Martin introduces the work of cult evangelization with a verse from 1 Peter, which he repeats again and again: "But sanctify the Lord God in your hearts: and be ready always to give an answer to every man that asketh you a reason of the hope that is in you." 35 In doing, he establishes the connection that he always upholds both explicitly and implicitly between genuine Christian devotion ("sanctify the

\footnotetext{
${ }^{34} \mathrm{KC} 1965,12$; KC 2003, 18.

351 Peter 3:15, King James Version. Martin, “The Do's and Don'ts of Witnessing to the Cults."
} 
Lord God in your hearts") and apologetics ("and be ready always to give an answer"). The two depend on each other. Consequentially, Martin's life work and the subject of the Kingdom is not meant for a small group of cult specialists but leads toward a renewal for the general community of Christians. Earlier scholarship on Martin has tended to read his focus as cast outside his own community onto the cults. Led by this connection that he makes so repeatedly, I read him as looking inward, at least as interested in acts of devotion through apologetics as in actually repudiating the cults. This devotion, furthermore, preferring doctrinal rather than sociological borders for the church, also serves to enact an ecclesial unity among believers from disparate sects and denominations bound by the defining doctrines of his orthodoxy.

The Kingdom is very clear about its purpose and how it is meant to be read. On the one hand, it claims to be (1) a scholarly exposition of the cults, and on the other, (2) a mission-field practicum for all Christians.

Our purposes in this volume are to further awaken interest in this tremendously important field of Christian missionary effort among the cults, to point out the flaws in the various cult systems, and to provide the information that will enable Christians both to answer cultists and to present effectively to them the claims of the Gospel of Christ, with a deep concern for the redemption of their souls. ${ }^{36}$

The challenge of the cults, Martin repeatedly points out, highlights the failure of ordinary Christians to be sufficiently knowledgeable about their beliefs. Cultists "are particularly effective among those in whom the early seeds of Christianity have been planted." "Young Christians, nominal Christians, and those who have only a passing acquaintance with the Scriptures" are most susceptible. ${ }^{37}$ Alongside warnings of the growing threat that cults and false religions represent, he argues that the only antidote to deception is a

${ }^{36} \mathrm{KC} 1965,16$; KC 2003, 23.

${ }^{37} \mathrm{KC}$ 1965, 325; KC 2003, 457. 
thorough understanding and the only protection for the eroding church is grassroots countercult activity on the part of all Christians. Martin explains, "If a man is thoroughly familiar with the original he will not be deceived by the counterfeit bill, no matter how much like the original it appears." ${ }^{38}$ By recommending the dissemination of doctrinal knowledge about both cults and Christianity, which in turn is internalized by the actingout of evangelizing, Martin traces a plan for reenforcing the borders of his orthodoxy.

Martin's approach to the erudite exposition of cults follows the pattern of Irenaeus, who wrote of the "cults" of the second century in Adversus Haereses, "The very manifestation of their doctrine is a victory against them." ${ }^{39}$ Irenaeus capitalized on (and perhaps exaggerated) the bewildering intricacy of the heretics' beliefs in order to contrast it to the simple truths of his Christian orthodoxy. Martin's account of the cults' misleading redefinitions of simple, commonly-understood doctrinal terms resembles this strategy, drawing also on the New Testament's abhorrence of sophistry. The assurance is that the cults will undo themselves when their history and doctrine are thoroughly examined. The Kingdom, in any edition, looks nothing if not thorough. While the 1965 version is 443 pages of small, unbroken text in two columns, the 2003 comes to just over 700 including bibliography, scripture index, and subject index. Especially by the latest edition, it gives each cult an extensive historical and doctrinal treatment. It takes the shape and form of the reference book genre (a "reference tool," as the 2003 dust jacket says), and with it, an air of objective authority.

Very early on, however, it is clear that the book is not intended to be used for entirely speculative, scholarly, or even polemic purposes. As it outlines the details of the

${ }^{38} \mathrm{KC} 1965,16$; KC 2003, 23.

${ }^{39}$ Irenaeus, Against the Heresies, 103. 
cults, the text assumes a missionary intention for its audience. The audience, as again the 2003 dust jacket explains, includes "both scholars and laypeople," and both are expected to participate in countercult work. Where it doesn't assume, it exhorts:

The evangelization of cultists is the task of the Christian church, of which each Christian is a member, a part of the body of Christ. ...It is excellent that we support foreign missions and send the light of God's Gospel around the globe, but it is quite another thing for us to begin here, where the demand is personal, challenging, and equally rewarding. This challenge is cult evangelism, the mission field on your doorstep. $^{40}$

Martin approaches his practice from two angles: personal performance and institutional reform.

When, from time to time, Martin speaks in the first person, he portrays himself as an experienced, professional, and successful cult evangelist. He generally used the title "Dr." and touted his academic credentials as an expert comparative religionist despite the questions critics raised about them. ${ }^{41}$ Doing so enacts an imitable identity. While explaining the technique of "subliminal seeding" (derived from the American advertising industry's "motivational research"), he describes instances of inviting over Jehovah's Witnesses into his living room in order to discuss their literature. ${ }^{42}$ He carries us through a typical encounter and makes it feel familiar. With the language of "doorstep" and "living room," the exhortation to evangelize comes, literally, close to home. At the same time, the crisis situation that the modern cults represent makes this work incumbent on all. In 1981, Martin published a Cults Reference Bible, an edition of the King James Version specially designed to help Christians respond to the misleading interpretations of

${ }^{40} \mathrm{KC}$ 1965, 352; KC 2003, 492.

${ }^{41}$ Shupe, for instance, takes Martin very seriously as a scholar and places him alongside Harvey Cox of Harvard in a comparative setting.

${ }^{42}$ KC 1965, 349-350; KC 2003, 488-489. 
scripture that cultists offer. By building his own presentation of the Bible itself, he further ensures that believers' everyday encounters with it are mediated by defining their orthodoxy against that of the cults. Study and "personal" evangelization together act as "immunization" against the temptation of cultism.

This sense of a democratized formulation of countercultism is reminiscent of Karl Rahner's tone in On Heresy, which arrived in English translation the year before the first Kingdom was published. Like Martin, Rahner argues that "the individual Christian is assigned and called irreplaceably to a task and a responsibility" to root out the creepingin of heretical doctrines. ${ }^{43}$ Both consider the opposition to falsehood an integral and necessary part of the Christian existence particularly in the circumstance of modernity. On the other hand, Rahner bases his exhortation on a model of heresy that is "hidden" and "latent," one that ultimately "cannot be determined in the abstract." ${ }^{44}$ Martin's insistence on the static orthodoxy formed in sola scriptura appears to differ from Rahner's model, which is founded more in the Catholic understanding of apostolic authority.

He explicitly refutes those who suggest a more passive stance, who would place cult evangelism less centrally in the life of a Christian. Twice, he takes on the speech of the Pharisee Gamaliel in Acts, which Marcus Bach uses to buttress his non-judgmental approach to the cults. ${ }^{45}$ In another stroke of exegesis, this time on 2 John 10, Martin

\footnotetext{
${ }^{43}$ Rahner, On Heresy, 66.

${ }^{44}$ Ibid., 48, 66.

${ }^{45}$ In the King James Version that the Kingdom uses throughout, Gamaliel says in his defense of the Christians, "Let them alone: for if this counsel or this work be of men, it will come to nought: But if it be of God, ye cannot overthrow it; lest haply ye be found even to fight against God." Martin argues that this speech is not framed by the text as inspired or authoritative. Acts 5:38-39; KC 1965, 13; KC 2003, 19-20; KC 1965, 340;
} 
resists those pastors who cautiously teach their flocks to avoid cultists rather than, "in the tradition of Christian evangelism, confront them with the claims of Christ." ${ }^{\text {46 }}$ With passages like this, and with the practical pointers for evangelizing offered throughout the book, he constantly asserts the Christian's "responsibility as an ambassador of Christ." By situating himself in settings as familiar as a living room, Martin sets an example for the appearance and performance of a renewed Christian devotion founded on his unifying orthodoxy.

In the last chapter of the Kingdom, "The Road to Recovery," Martin lays out in detail his plan for the other half of the apologetic project, institutional transformation in the church. It consists in four ambitious parts: (1) thorough and sustained research on the cults and their doctrines, (2) a computer retrieval system to store and make publicly accessible the data on the cults (remember he's writing in 1965!), (3) proliferation of extensive countercult printed literature, and (4) a renewed emphasis on cults and false religions in mainstream Christian education. ${ }^{47}$ What these amount to is a wholesale shift in the attention of the church, an integration of the countercult movement into the core idea of what the church exists to do.

Walter Martin himself worked hard toward these large-scale goals in his lifetime. His CRI apparently continues to carry on research into the cults, and Walter Martin Ministries promulgates his extensive writings and recorded lectures on cults. More recently, the internet is making the computer system he imagined a reality through a

KC 2003, 476; Bach, 20.

${ }^{46} 2$ John 10, again in KJV, reads, "If there come any unto you, and bring not this doctrine, receive him not into your house, neither bid him God speed." Martin takes this to be directed at the congregation, that heretics should not be allowed to teach, not that they should not be confronted. KC 1965, 346; KC 2003, 485.

${ }^{47}$ KC 1965, 353-355; KC 2003, 496-499. 
number of websites. The Kingdom itself, as a Christian bestseller, has served as a model and a source for decades in the development of countercult activities in print and electronic media. Still it remains to be determined the extent to which these activities have directed the interest of the majority of Christians more onto countercult evangelism.

With a tendency toward cult of personality that has never been uncommon among American evangelists, Martin put forward an imitable performance with his own public persona of a unifying orthodoxy amdist disparate denominations and groups. The primarily doctrinal nature of his orthodoxy was built to be carried out in an evangelizing practice. The institutional structures he imagined, furthermore, likely represented the beginning of a more tangible unity for the church, built on the dissemination of countercult activity among Christians. But even while Martin's orthodoxy is firmly built on this activity, on praxis, he interestingly devotes hardly any attention to orthopraxis, to a community defined by its exterior and ritual practices. He implicitly suggests a separate category entirely, an enacted orthodoxy, in which borders are drawn distinctly in terms of belief, which in turn is entrenched, recognized, and shared through a certain kind of performance. Turning doctrinal knowledge into a practiced activity, he challenges Christians to better internalize what he takes to be the central teachings of the faith. This performance, though, need not look the same in every case. By accepting the Catholic Church $^{48}$ and the Seventh Day Adventists alongside Baptists and Methodists, Martin asserts that orthodox believers may behave rather differently from each other. He retains an insistence that belief, powerful enough to be salvific, is also powerful enough to

\footnotetext{
${ }^{48}$ The Catholic Church is hardly mentioned at all in the Kingdom, but in other works, Martin showed willingness to include it within his orthodox umbrella, which proved a controversial move.
} 
demarcate the holy community clearly.

\section{Conclusion: Genre and Comparison}

In my introduction I suggest that there is some usefulness in thinking about The Kingdom of the Cults, or indeed any contemporary work of this sort, in terms of the genre of heresiology, epitomized by Irenaeus's second century Adversus Haereses and Epiphanius's fourth century Panarion. Given the broad range of circumstances that our extant heresiological sources come from, the word "genre" has to be used with some care. It is difficult to know the extent of this kind of literature available in the time of Epiphanius or Irenaeus, and therefore the expectations their audiences might have had in mind. Martin makes it easy enough to trace his sources and references, which include heresiology proper (Van Baalen) as well as less polemical catalogs of curiosities (Branden, Bach). More recent works that follow his, though each treats cults, false religions, and heresies according to a slightly different taxonomy, have certainly built a genre on the shelves of today's evangelical Christian bookstores. What all these have common, constituting a genre in the loosest sense from Irenaeus to Martin's followers, is best defined simply: heresiology is a catalog and refutation of heresy.

In the context of critical scholarship, however, heresiology has come to serve as a source for understanding the notion and construction of heresy in religious communities to begin with, as well as its close relative, orthodoxy. This inquiry, withholding judgment on the theologies of these terms, has adopted a more sociological approach, recognizing the power they have to shape and bound the groups in which they operate. 
One writer, for instance, observes that "the aim of orthodoxy is to convert difference into exclusion." ${ }^{49}$ Another, even while recognizing the historical difficulties of defining the genre too specifically, concludes that "one ought to read these compositions ...[as] selfperpetuating constructions that helped to formulate thought and underpin social norms."

By either manner of definition, the Kingdom fits into the genre as well as any premodern example. Quite plainly it catalogs heresies and refutes them. As scholars have come to realize, from Bauer to Boyarin and Martin himself, any account of heresy depends on a theory of orthodoxy. His "ramparts" serve as just this. Heresy also bears important social consequences. The sociological disunity of Martin's church informs his contrasting emphasis on a doctrinal basis for orthodoxy. With examples like the Seventh Day Adventists and the Worldwide Church of God, the book takes potentially controversial stands on questions of inclusion and exclusion. Also, by extending theories into a social practice of active evangelization and institutional reform, it offers definite models for converting difference into outright exclusion.

As a result of these characteristics that it shares with the genre of heresiology, the Kingdom and works like it should serve, with care, as comparative aids in the interpretation of premodern texts, and vice versa as well. In addition, the priority we give to premodern heresiology in reconstructing the communities that created them should endow their modern counterparts with a similar priority. They are undoubtedly significant articulations of where orthodoxy and heresy are today. A work like the Kingdom specifically, which has been consistently revised and selling well for over forty years, should be recognized for its impact in helping to generate these "self-perpetuating

${ }^{49}$ David Runia, review of La notion d'heresie, 190.

${ }^{50}$ Cameron, "How to Read Heresiology," 483. 
constructions."

I will finish with a small example of comparison between the Kingdom and Epiphanius's Panarion which might help to clarify my final observations about performance in Walter Martin's project. At the end of the last section, I suggest that Martin outlines a practice of enacted orthodoxy, one which is importantly different from simply orthopraxis. In the Panarion, on the other hand, Epiphanius develops both an orthodoxy and an orthopraxis, distinct yet packaged together as part of his in-group of proper Christianity. Briefly exploring their diverging frameworks should open up productive questions for future discussion.

Ephiphanius concludes his work with a lengthy chapter that modern editors have called De Fide: in his words, "A concise, accurate account of the faith of the Catholic and Apostolic Church." ${ }^{, 1}$ After three books of exposition against the heresies, he offers a telling of the story of Jesus Christ and the beliefs of Christians, particularly with regard to salvation history and, a bit like Martin, the meanings of theological terms. The last few pages of this chapter, however, take a different tack. Having already "spoken briefly of the tenets of the faith," he turns to the practices "observed by the church, some by commandment, others by vonuntary acceptance.. ${ }^{, 2} \mathrm{He}$ goes on to describe the observances of the monks and virgins (including the lengths at which they keep their hair), the Sabbath and ritual fasting, baptism, the limited leadership of women ("Only to assist women for modesty's sake"), forbidden articles of clothing and devotion, and the details of clerical hierarchy. Importantly also, "the church refrains from fellowship with any other sect."

${ }^{51}$ Epiphanius, The Panarion of Epiphanius of Salamis, 638.

${ }^{52}$ Ibid., 661-665. 
Martin does nothing of the sort. He never even brings up the issues of moral behavior that have become hot-button talk in more recent evangelical discourse, like abortion and marriage. The Christian community is a body constituted by its theological beliefs plainly and securely. For Epiphanius, these features of what I would call orthopraxy, right behavior, are part of "the character of the church." Placed eminently last in his work, they have a special importance as the visual, cultural signifiers of the true faith. The Kingdom, however, goes the opposite way. Sects like the Seventh Day Adventists show that even those that act strangely can still be considered orthodox if they have their beliefs right. Yet at the same time, Martin is deeply concerned with Christian practice of a different kind, the countercult apologetics that he exhorts his readers continually to participate in. Through this enacted orthodoxy, however, activity serves not so much to identify the community (the way it does for Epiphanius) as to psychologically entrench doctrinal orthodoxy as the unifying sign of the rightly-guided church.

Though comparison of such disparates cannot safely go beyond these moments of clarifying insight, it can help to reveal and highlight certain characteristics and unseen significances, particularly in times and places so obscure as the distant past and the immediate present. 


\section{Bibliography}

Bach, Marcus. They Have Found a Faith Indianapolis: Bobbs-Merrill, 1946.

Bauer, Walter. Orthodoxy and Heresy in Earliest Christianity. Minneapolis, MN: Fortress Press, 1971.

Boyarin, Daniel. Border Lines: The Partition of Judeo-Christianity. Philadelphia: University of Pennsylvania Press, 2003.

Branden, Charles S. These Also Believe. New York: MacMillan, 1949.

Cameron, Averil. "How to Read Heresiology." Journal of Medieval and Early Modern Studies 33, no. 3 (Fall 2003).

Cowan, Douglas E. Bearing False Witness? An Introduction to the Christian Countercult. Westport, Conn.: Praeger, 2003.

_ "Historical Figures in the Christian Countercult Movement: Walter R. Martin." The Religious Movements Homepage Project at the University of Virginia. http://religiousmovements.lib.virginia.edu/cultsect/counter/martin.htm

Desjardin, Michael. "Bauer and Beyond: On Recent Scholarly Discussions of Haireseis in the Early Christian Era." The Second Century 8 (1991): 65-82.

Epiphanius. The Panarion of Epiphanius of Salamis. Translated by Frank Williams. Leiden: Brill, 1994.

Irenaeus. St. Irenaeus of Lyons Against the Heresies. Translated by Dominic J. Unger. New York: Paulist Press, 1992.

Martin, Walter R. The Kingdom of the Cults. Minneapolis: Bethany Fellowship, 1965.

—.Walter Martin's Cults Reference Bible. Vision House, 1981.

- The Kingdom of the Cults. Edited by Ravi Zacharias, et al. Minneapolis: Bethany House Publishers, 2003.

—. "Walter Martin's Religious InfoNet - Biography." From Walter Martin's Religious InfoNet. http://www.waltermartin.org/bio.html.

—. "The Do's and Don'ts of Witnessing to the Cults." From Walter Martin's Religious InfoNet. http://www.waltermartin.org/dodont.ram.

Olsen, Roger E. "Tensions in Evangelical Theology." Dialog: A Journal of Theology 42, no. 1 (Spring 2003): 76-85. 
Rahner, Karl. On Heresy. New York: Herder and Herder, 1964.

Runia, David. Review of La notion d'heresie dans la litterature grecque IIe-IIIe siecles, by Alain Le Boulluec. Vigiliae Christianae 42, no. 2 (June 1988).

SHIELDS (Scholarly \& Historical Information Exchange for Latter-Day Saints). "The Myth Surrounding Walter Martin's Death." http://www.shieldsresearch.org/Critics/Mar_myth.htm.

Saliba, John. Understanding New Religious Movements, 2nd ed. Walnut Creek, CA: Altamira Press, 2003.

Shupe, Anson Jr. Six Perspectives on New Religions: A Case Study Approach. New York: E. Mellen Press, 1981.

Van Baalen, Jan Karel. The Chaos of the Cults: A Study in Present-Day Isms. Grand Rapids, MI: Eerdmans, 1938.

Williams, Rowan. "Does It Make Sense to Speak of Pre-Nicene Orthodoxy?" The Making of Orthodoxy: Essays in Honor of Henry Chadwick, ed. Rowan Williams. Cambridge: Cambridge University Press, 1989. 